\title{
Research about Bilingual Education Issues in Business Intelligence Teaching
}

\author{
Jian Chen \\ Economic and Management School \\ Shanghai Polytechnic University \\ Shanghai, China
}

\author{
Yang Ying \\ Economic and Management School \\ Shanghai Polytechnic University \\ Shanghai, China
}

\begin{abstract}
This paper raises three issues about teaching in business intelligence class, including class content, talents abilities, and practical abilities. Based on the teaching experiences on this class, this paper provides frameworks to combine bilingual, extends, professional teaching materials as inner-class content and extracurricular activities, English forum, business visit as outer-class content together to improve the quality of class. Create projects, competitions, oversea studies, and finally entrepreneurship to develop student talents. Followed by with laboratories and training camp to improve students' practical skills of business intelligence. Finally, the paper discusses different approaches to achieve the goals above with different aspects.
\end{abstract}

Keywords-Teaching methods; bilingual teaching; business intelligence class;

\section{INTRODUCTION}

Business Intelligence (BI) is bringing tremendous changes to the pattern of World Trade and the mode of economic growth, it has become one of the main tools for economic and trades in the 21st century. As the technology and form of new business intelligence are disseminated in English first, the internationalization of business intelligence is becoming increasingly demanding. It makes English Teaching in business intelligence class become more important than ever. However, the teaching of English in Business Intelligence still presents the situation of the division of curriculum and specialty, which leads to the repeatability and inefficiency of teaching and is not conducive to the cultivation of talents.

While the research, teaching and application of Business Intelligence (BI) in foreign countries have been highly valued and a series of important achievements have been achieved, there are some problems in BI teaching in China, such as the disconnection between theoretical knowledge and international situation, the obsolescence of cases, the mismatch between teaching methods and current situation, and the interaction between teachers and students. Long standing problems such as foot. On the other hand, under the background of economic globalization and China's economic integration into the global economy, the ability to think, work and communicate in the international language has been paid more and more attention.

2nd Laboratory construction of Intelligent manufacturing center"(A11NH182019) / Curriculum construction of Shanghai Polytechnic University_Business Intelligence (A01GY18F014-03).
This ability has also become an effective tool for Chinese talents to participate in international competition. Finally, through all-English teaching, bilingual teaching and related courses construction of the relevant business intelligence classes in recent years, the professional classes and teachers have realized the importance of international teaching in business intelligence majors should actively carry out the internationalization of education so that students can have a strong international communication ability in their professional fields. At the same time, it should broaden its international vision, enhance the ability of cross-cultural communication and cooperation, and participate in international competition to meet the needs of national economic and social development.

In view of this, this paper aims to break the separation between Business Intelligence Specialty and English teaching, combine them organically and penetrate each other, construct a comprehensive, systematic, step-by-step, coherent bilingual teaching system of Business Intelligence, so as to cultivate international students with certain academic English communicative ability and high humanistic quality[1][2]. Applied and innovative talents.

\section{CURRENT ISSUES NEED TO STUDY}

\section{A. How to Implement Effectively of Class Content Management in International Teaching System}

Currently, the business intelligence class offered by colleges and universities is still under the traditional teaching mode, the teaching system and teaching planning cannot catch up with the rapid knowledge development, the teaching of business intelligence in Colleges and universities is still in the traditional foreign trade environment or computer science mode, which is separated from the system of current business intelligence situation. Hence, how to effectively strengthen the internationalization of teaching content management, enable students to effectively learn the internationalization of the course content, and can learn the knowledge of digestion and absorption, and ultimately improve the internationalization ability is the project to solve the problem 


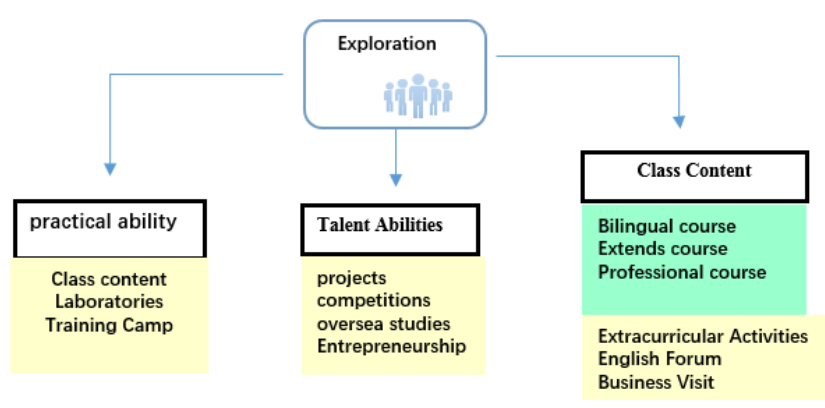

Fig.2 Exploration framework of business intelligence specialty

The Business Intelligence class will adopt the content management method as shown above. The English keywords related to the course and the original English cases will be inserted into the professional technology course and the professional management course to discuss and analyze with the students in the classroom [4]. Because the major is an engineering degree, the professional technology course can let the students in the course. After that, participations in the discussion on the basis of the English specification and the English technical forum will be held.

\section{A. Projects and Competitions}

Each semester, teachers will organize students to actively apply for school-level technology and innovation projects. According to the students' interest and technical level, the topic of project with related content will be determined after discussion with teachers. The teacher will pre-check and predefense the students' ideas to ensure the success rate of student project declaration. In the process of project execution, teachers and students regularly discuss the progress of the project and solve the difficulties of the project. In order to improve students' ability to solve projects. After get experiences of school-level projects. Teachers would actively encourage students to participate in business intelligence competitions, including municipal and national business intelligence competitions. This will make students gain more on-hand experience and confidence in business intelligence areas, teachers also will have wider views about the class they teaching [5][6].

\section{B. Overseas studies}

Students of this class should have opportunities to overseas colleges and universities as exchange students to learn advanced foreign business intelligence technology and concepts. Professional teachers also should encourage students to participate in overseas exchange programs.

\section{Entrepreneurship}

The entrepreneurial passion of this major student has always been very good. The project team members will guide students to take an active part in the business activities of international business intelligence. This will greatly help students understand and improve their practical ability.

\section{The innovation of Course content}

This paper attempts find a way to add English materials related to the course to the existing curriculum content, and summarizes the English words and professional meanings that must be mastered in the course. We should fully mobilize and give full play to students' subjective initiative and enhance the interactive relationship between teachers and students [7]. To some extent, students can be trained to listen, speak, read, and write business correspondence manuscripts and professional terms commonly used in business intelligence enterprises [8].

\section{E. Laboratories and Training Camp}

Forming a school-enterprise cooperation-based model, schools and enterprises jointly build a business intelligence practice teaching base, and cooperate with international business intelligence enterprises to formulate and implement a joint training plan for professional courses, business and information technology practice [9]. Emphasis should be placed on fostering students' International Literacy, controlling risks and uncertainties, initiative and learning ability.

\section{F. Extracurricular Activities}

In order to better implement the goal of training international business intelligence students, it should integrates the teaching and research team of this specialty and the teaching and research group of professional economics and management. Through training and academic exchanges, it strengthens the construction of learning team, thus improving the overall scientific research and teaching level of the team [10]. For example, organize professional teachers to participate in all kinds of international business intelligence teaching seminars, curriculum training, etc [11].

\section{G. Business Visit}

Business intelligence industry, cross-border e-commerce industry participants to the school for a series of industry reports and industry lectures. This is also a learning opportunity for our project team members to increase understanding and teaching of the industry.

\section{SUMMARY}

This paper represents an idea that implementing the internationalized teaching of Business Intelligence so that English teaching and professional teaching are no longer unrelated, but are integrated into the teaching of professional courses, laying a solid foundation for bilingual or all-English teaching of various professional courses, thus building a comprehensive and systematic teaching system of Business Intelligence.

Through a variety of forms and methods of teaching practice to improve students' internationalization ability, this project will pay more attention to comprehensive case practice, mature project training, actual environment and other forms and methods of teaching practice. In particular, students are encouraged to improve their internationalization ability by strengthening the cultivation of network interaction ability, team cooperation ability and project organization ability. 


\section{ACKNOWLEDGMENT}

This paper is support by project "2nd Laboratory construction of Intelligent manufacturing center"of shanghai polytechnic university (A11NH182019) and Curriculum construction of shanghai polytechnic university_Business Intelligence (A01GY18F014-03).

\section{REFERENCES}

[1] Lanxin Hu.Exploration Teaching Method of "Communication Engineering" Technical Talents[C]2016.

[2] Xuan Chen,Huimin Zheng.Educational Reform of Car Marketing Teaching Based on Project-driven Method[C]2016.

[3] Li Yan.Professional Interpreters Teaching Method Research in Undergraduate Education[C].//International conference on social science and technology education: ICSSTE 2015, Sanya, China, 11-12 April 2015, Part 2 of 2.College of Foreign Languages and Cultures, Xiamen University,2015:1018-1023.

[4] Yeyu Chen.The Analysis of Techniques for Learning a Foreign Language through Translation[C].//International conference on social science and technology education: ICSSTE 2015, Sanya, China, 11-12 April 2015, Part 2 of 2. Minnan Science and Technology Institute, Fujian Normal University,2015:660-662.
[5] Dachun Zhang.Construction of Physical Education Assessment System Based on Information Technology[C]./International conference on education technology, management and humanities science: ETMHS 2015, Xi an, China, 21-22 March 2015, Part 1 of 2.Physical Education Department of Heihe University,2015:347-350.

[6] CHI Xiao-peng.The Research on the Application of Computer Simulation in Competitive Aerobics Teaching and Training[C]./International conference on education technology, management and humanities science: ETMHS 2015, Xi an, China, 21-22 March 2015, Part 2 of 2.Department of Physical Education \% Research, Beijing Foreign Studies University,2015:1030-1033.

[7] Li jing Wu.Research on Innovation of Bilingual Teaching Mode for Postgraduates in Local Colleges[C].//The 2016 2nd International Conference on Economy,Management,Law and Education(EMLE 2016) 2016:483-486.

[8] Zhang Yi,Wang Shanshan.The Goals of Foreign Language Teaching in Engineering Education and Their Implementation at DNUI[C]2017:359367.

[9] Sisi Zhang.Analysis on the Bilingual Teaching of Art Design in Sinoforeign Cooperative Education Take China-New Zealand Cooperative Training Project of Chengdu University as Example[C].//2016 2nd International Conference on Arts,Design and Contemporary Education(ICADCE2016) 2016:413-416.

[10] ValdezVerónica E.,DelavanGarrett,FreireJuan A..The Marketing of Dual Language Education Policy in Utah Print Media[J].Educational Policy,2016,(6):849-883. DOI:10.1177/0895904814556750.

[11] Gabriela Sylvia Meier.The multilingual turn as a critical movement in education: assumptions, challenges and a need for reflection[J].Applied Linguistics Review,2017,(1):131-161. DOI:10.1515/applirev-2016-2010. 